\title{
Bryophyllum Pinnatum leaf (BPL) is an eternal source of renewable electrical energy for future world
}

\author{
Md. Kamrul Alam Kahn ${ }^{1}$, Mohammad Hasan Bakshi ${ }^{2}$, Abdullah Al Mahmud ${ }^{3}$ \\ ${ }^{1}$ Department of Physics, Jagannath University, Dhaka, Bangladesh \\ ${ }^{2}$ Department of Physics, Jatrabari Ideal School and College, Dhaka-1204, Bangladesh \\ ${ }^{3}$ Department of EEE, World University of Bangladesh, Dhaka-1205, Bangladesh
}

Email address:

kakhan01@yahoo.com (Md. K. A. Khan), bakshi.sir81@gmail.com (M. H. Bakshi), aamahmudeee@yahoo.com (A. A. Mahmud)

\section{To cite this article:}

Md. Kamrul Alam Kahn, Mohammad Hasan Bakshi, Abdullah Al Mahmud. Bryophyllum Pinnatum Leaf (BPL) is an Eternal Source of Renewable Electrical Energy for Future World. American Journal of Physical Chemistry. Vol. 3, No. 5, 2014, pp. 77-83.

doi: 10.11648/j.ajpc.20140305.15

\begin{abstract}
Modern civilization uses huge amount of electrical power. Most of this power is generated by using fossil fuel which is non-renewable and we can not produce it according to our desire .If this condition continue human civility will face great difficulties. In this case energy solution for the future will increasingly depend upon the uses of renewable energy. Keeping this concept in mind, an Innovative work has been designed and developed at the Physics Department of Jagannath University, Dhaka, Bangladesh. Electrochemistry and electrical Performances have been studied. The concentration of the reactant and product ions are $\left[\mathrm{Cu}^{2+}\right]$ and $\left[\mathrm{Zn}^{2+}\right]$ respectively measured by the Atomic Absorption Spectrophotometer (AAS). The variation of $\left[\mathrm{Cu}^{2+}\right]$ and $\left[\mathrm{Zn}^{2+}\right]$ with the variation of time, temperature of the electrolyte, concentration of the juice ,distance between two plates, absorption and adsorption of the $\left[\mathrm{Cu}^{2+}\right]$ and $\left[\mathrm{Zn}^{2+}\right]$ by the electrodes, thickness of the electrodes have been studied. Voltage regulation, Internal resistance, Energy efficiency, Current efficiency, Voltage efficiency, Charging efficiency, Discharging efficiency, Open circuit Voltage, Short circuit Current of the BPL cell have been studied. It has been also studied the Voltage regulation, Internal resistance, Energy efficiency, Current efficiency, Voltage efficiency, Charging efficiency, Discharging efficiency, Open circuit Voltage, Short circuit Current of the BPL cell with the variation of time. The name and presentation of the BPL cell has been developed. It has been introduced the name of the BPL cell as quasi Galvanic/Voltaic cell. Most of the results have been tabulated and graphically discussed.
\end{abstract}

Keywords: Electrochemistry, Electrical Performances, Absorption Spectrophotometer (AAS), Voltage Regulation, Internal Resistance, Energy Efficiency, BPL Cell, Current Efficiency, Bryophyllum Pinnatum

\section{Introduction}

In our research we used juice of a leaf which scientific name is Bryophyllum Pinnatum .In some countries it is called mother leaf or miracle leaf. In Bengali it is called PATHORKUCHI leaf. Generation of electricity from mother Leaf is quite simple. It is possible to produce electricity from BPL even for a layman. Though the produced voltage and current as well as the power is low but there is almost no danger for human as the usual electricity has. To get the electricity from BPL we have to undergo with some very simple process. These processes are as below:

Collecting and making Juice of BPL, Collecting Zinc and Copper Plates as electrodes and the appropriate container, Placement of Zinc and Copper plates in the container,
Connecting the Zinc and Copper plates in proper way.

\subsection{BPL Unit Cell}

A simple BPL unit cell can be made from copper and zinc metals with solutions of BPL juice. In the process of the oxidation and reduction reactions, electrons can be transferred from the zinc to the copper through an electrically conducting path as a useful electric current. The fabricated Unit cell of BPL electric voltage is around 1.1 volt. The BPL electricity depends on various parameters. The parameters are given by the following:

Concentration of the malt, area of the electrodes, distance between the two electrodes, the constituent elements of the electrodes. The volume of the BPL malt / juice, the temperature of the BPL malt, the age of the BPL juice, $\mathrm{P}^{\mathrm{H}}$ 
value of the BPL juice.

The BPL unit cell is illustrated in Figure 1

A BPL unit cell can produce only 1.1 voltages which is not sufficient to meet the practical situation. Therefore to meet the pragmatic application BPL cells are grouped in module and panel.

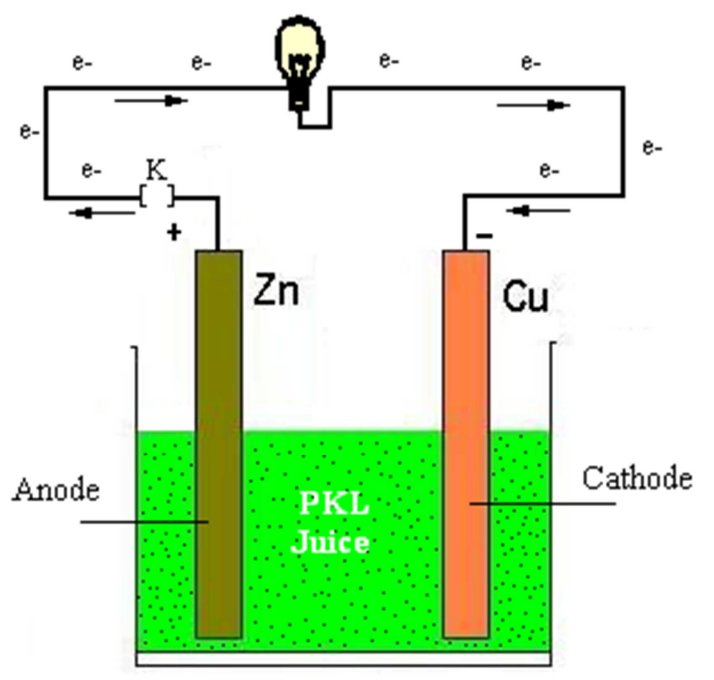

Figure 1. BPL Unit cell.

\subsection{BPL Electric Module}

It is made by more than one Unit cell. The BPL Unit cells are connected by wires. The voltage of the electric modules is more than 6.6 volts. A six cell BPL module is shown in figure 2 .

\subsection{BPL Electric Panel}

A BPL electric panel is made of more than one BPL electric modules by physically and electrically connected. The voltage of the BPL electric Panel is higher than the BPL electric modules. A BPL panel with three modules is shown in figure 2 .

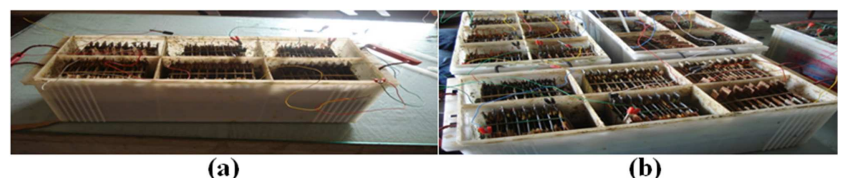

Figure 2. BPL Electric Module and Panel.

\section{Collecting and Making Juice of BPL}

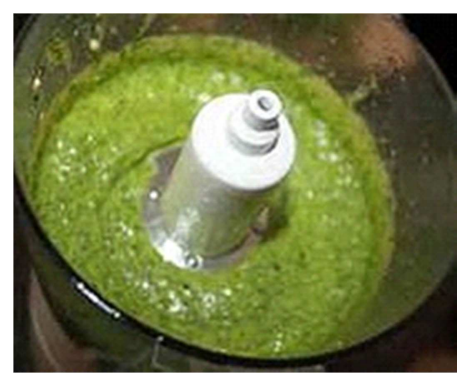

Figure 3. Preparation of Juice of BPL
In order to produce electricity from the leaf of the Bryophyllum Pinnatum, first of all we need to collect its leaf. After washing and cleaning need to blended by blenders.

Thereafter a mixture, containing pest and water with proportion generally $8: 1$, will have to be prepared. This mixture can be used directly for electricity generation. This juice can be filtered out to get the clean juice for the use of electricity production. Figure-3 shows the picture of preparation process of juice.

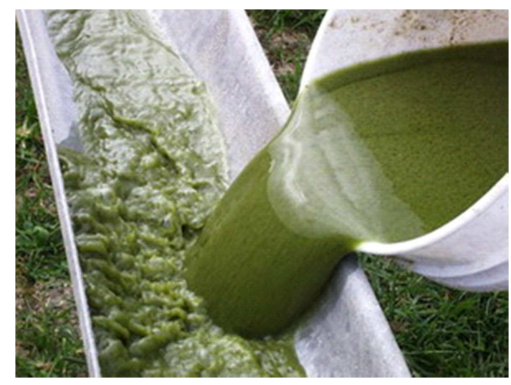

Figure 4. Prepared Juice of BPL

After blending the immaculate juice is reserved in a plastic container or pot. This juice can be stock there for long time. Figure: 4 shows the picture of prepared fresh juice.

\subsection{Preparing Electrodes}

For the production of electricity we need to make the electrodes for BPL cell. To make a cell we need two plates for the production of electricity. One is Zinc plate and other is Copper plate. Zinc plate acts as negative plate or negative terminal and copper plate acts as positive plate or positive terminal .In local market the Zinc and copper plates are available is large sheet forms. They can be cut into pieces according to the size of the cell. The Zinc plates are dissolved in the solution during the production of electricity but the copper plates do not melt. In shot zinc plate is used as cathode, where copper used as anode. Figure 5 shows the typical preparation of Zinc and Copper plates.
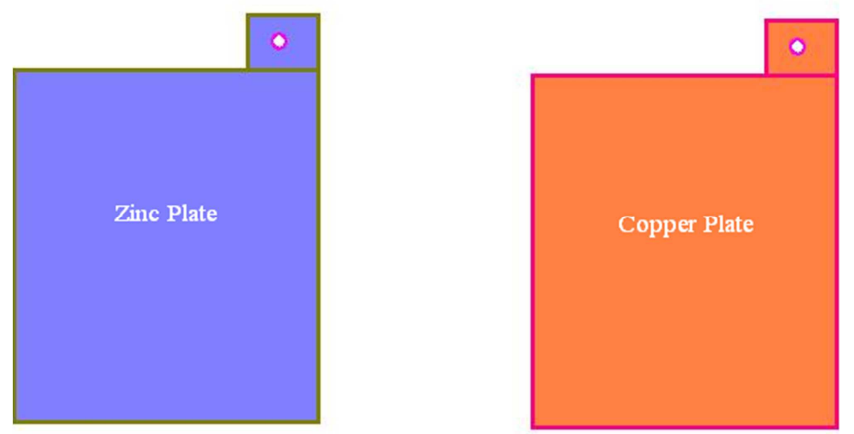

Figure 5. Preparing of Zinc Plates and Copper plates for use in the production of electricity from BPL cell.

\subsection{Placement of Electrodes}

At this stage we need the plastic container or pot to arrange the plates. We can also use clay receptacle as the substitute of plastic container. This plastic container can be 
easily found in the market in different size as battery box. Now the Copper plates and Zinc plates are placed or pretend in the container one after another. That is if we start with Zinc plate than first a Zinc plate than a Copper plate than a Zinc plate than again a copper plate and so on. In reverse way, if we start with Copper plate than first a Copper plate than a Zinc plate than a Copper plate than again a Zinc plate and so on. It should be noted that we have to follow only one sequence for all the cells in a particular battery arrangement.

A typical sequence with Zinc plate is shown in figure: 6
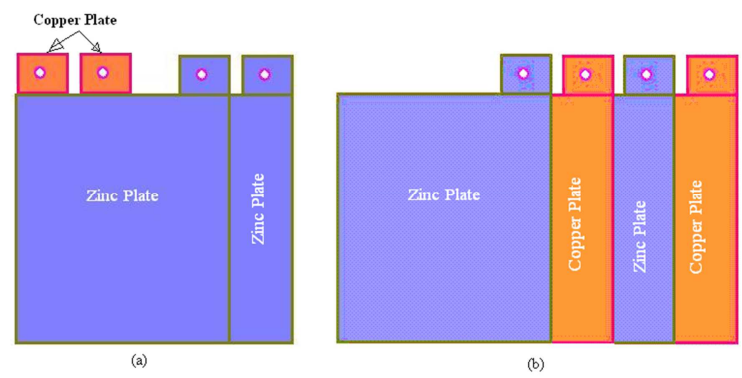

Figure 6. Arrangement of plates keeping Zinc plate first.

This arrangement of plates can also be done keeping the copper plate first i.e. first a Copper plate than a Zinc plate than a Copper plate than again a Zinc plate and so on. A typical sequence with copper plate is shown in figure: 7
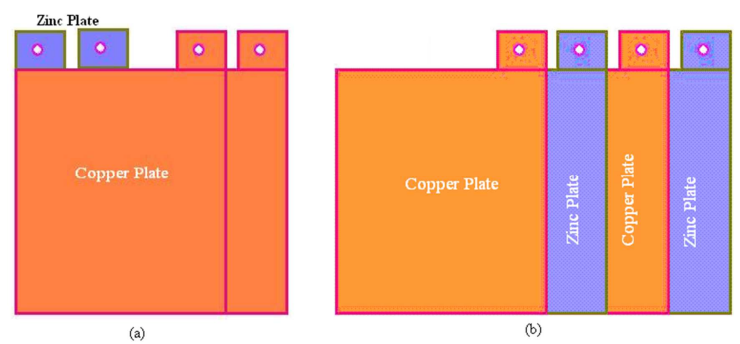

Figure 7. Arrangement of plates keeping Copper plate first.

\subsection{Making Connections between Electrodes}

After successful arrangement of the plates we need to make internal connection between plates. It may be noted here that the Copper plate will be the Positive plate and the Zinc plate will be the negative plate. So in a particular cell we have to connect all the Zinc plates together and all the copper plates together. A typical illustration of connection is shown in figure 8 keeping the zinc plate first.
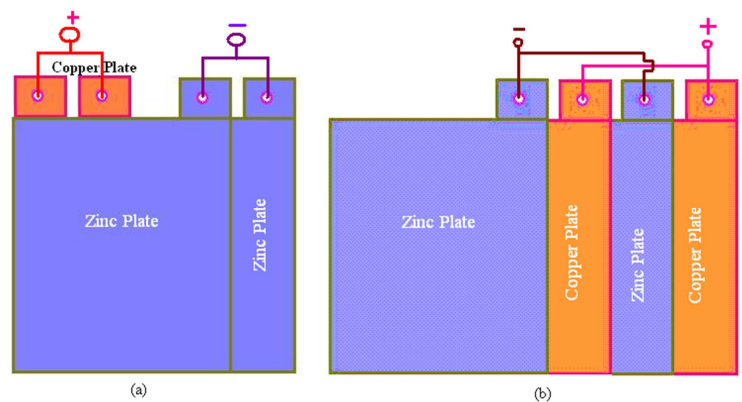

Figure 8. Connection arrangement of plates keeping the Zinc plate first.
For the group of plates keeping the Copper plate first, the same connection shall be made connecting all the copper plates in one group and all the Zinc plates in another group using copper wire. A typical illustration of connection is shown in figure 6 keeping the Zinc plate first. It is noted that we should keep some gap between copper and zinc plate as it were the two plates always remain untouched. For better result we can use a suitable separator in between two plates. But keep in mind that the plates should be as close as possible to get the better output.
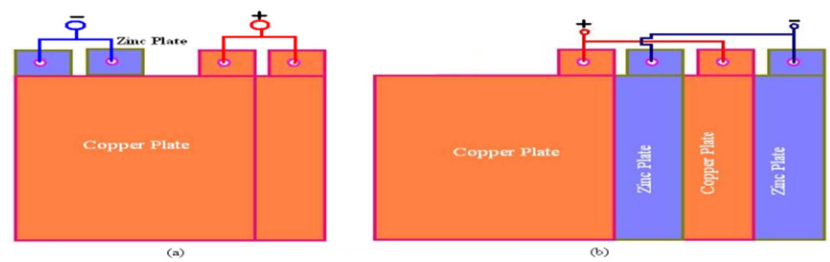

Figure 9. Connection arrangement of plates keeping the Copper plate first.

In this way Copper plat and Zinc plate should be placed in cell. If we use more plates per cell current shall be increased keeping the per cell voltage fixed. Theoretically per cell voltage of BPL is 1.1 volts.

\subsection{Series and Parallel Combination Characteristics of Cells}

Series combination and parallel combination of cells is very much important to get the desired voltage and current as well as power from the system. These are discussed below.

\subsection{Series Combination of Cells}

When two or more cells are connected in series than the combination is called series combination of cells. In this case the positive terminal of one cell shall be connected with the negative terminal of the other cell and the positive terminal of that cell will be connected with the negative terminal of the next cell and so on. In this case the cells voltages are add to give the output voltage but output current remains the same as a single cell. This combination is used when the increased system voltage is required. Let us consider the case of dry cell battery each cell with cell voltage 1.5 volts. Now if we want to run an appliance the voltage rating of which is 6 voltage than we need 6 divided by 1.5 equals 4 cells [i.e. 6 $/ 1.5=4$ cells] in series to get six voltage and to get it we have to connect the sells in series. That is, the positive terminal of one cell shall be connected with the positive terminal of the load and negative terminal will be connected with negative terminal of the load or appliances. This arrangement is shown in figure 10 below.

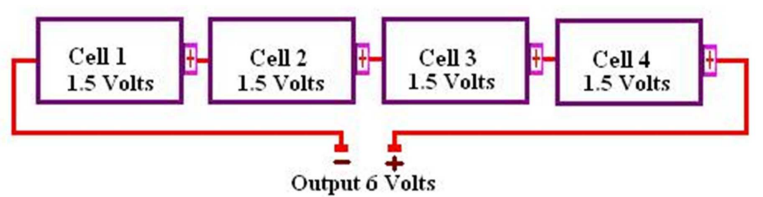

Figure 10. Series Combination of Cells. Voltage is four times higher of each cell voltage. 
Here each cell voltage $=1.5$, Number of cell in series $=4$, Therefore, System voltage $=$ Each cell voltage $\times$ Number of cell in series. i.e. System Voltage $=1.5 \times 4$ Volts $=6$ Volts

System current $=$ One cell current.

In general, for system voltage, $\mathrm{V}$ System $=\mathrm{V}$ Cell $1+\mathrm{V}$ Cell $2+\mathrm{V}$ Cell $3+\ldots \ldots \ldots+\mathrm{V}$ Cell n, i.e. $\mathrm{V}$ System $=$ $\sum_{\mathrm{n}}^{\mathrm{x}=1} \mathrm{~V}_{\text {Cell } \mathrm{x}}$, For system current, I System $=\mathrm{I}$ Cell $1=\mathrm{I}$ Cell $2=\mathrm{I}$ Cell $3=\ldots=$ I Cell $n$

\subsection{Parallel Combination of Cells}

When two or more cells are connected in parallel than the combination is called parallel combination of cells. In this case the positive terminals of all the cells are connected together and forms the positive terminal of the system and all the negative terminals of all the cells are again connected together to form the negative terminal of the system. In this case the sells currents are add to give the output current but output voltage remains the same as a single cell. This combination is used when the increased system current is required. Let us again consider the case of same dry cell battery each cell with cell voltage 1.5 volts. Now if we want to run an appliance the voltage rating of which is 1.5 volts but current rating as high as four cells. In such case we need to connect the cells in parallel which will increase the system current four times but will keep the system voltage the same i.e. 1.5 volts. The positive terminal of all the cells shall be connected with the positive terminal of the load and negative terminal of all the cells shall be connected with negative terminal of the load or appliances. This arrangement is shown in figure 11 below.

Here each cell voltage $=1.5$, Number of cell in parallel $=4$, Therefore, System voltage $=$ One cell voltage $=1.5$ Volts, System Current $=$ Each cell Current $\times$ Number of cell in parallel. i.e. System Current $=($ Each cell current $\times 4)$ Ampere,

In general, for system Current, I System $=$ I Cell $1+$ I Cell $2+$ I Cell $3+\ldots \ldots \ldots+$ I Cell $n$

i.e. I System $=\sum_{n}^{x=1} I_{\text {cell } x}$, For system Voltage, VSystem $=$ VCell $1=$ VCell $2=$ VCell $3=.=$ V Cell $n$

Table 1. Calculation of efficiency of BPL modules with time.

\begin{tabular}{|c|c|c|c|c|}
\hline Date & Time & Potential without load, $\mathbf{E}_{\max }$ & Potential with load, $\mathrm{E}$ & $\operatorname{Efficiency}(\eta \%)=\mathrm{E} / \mathbf{E}_{\max } \times 100 \%$ \\
\hline $28-08-13$ & $5: 00 \mathrm{PM}$ & 6.16 & 5.85 & 94.97 \\
\hline $28-08-13$ & 9:30PM & 4.98 & 3.80 & 61.69 \\
\hline $29-08-13$ & 12:00PM & 4.55 & 3.78 & 61.4 \\
\hline $29-08-13$ & $3: 30 \mathrm{PM}$ & 4.00 & 3.45 & 56.00 \\
\hline $29-08-13$ & 7:30PM & 3.65 & 3.30 & 53.57 \\
\hline $30-08-13$ & 3:00PM & 3.53 & 3.24 & 52.6 \\
\hline $30-08-13$ & 8:00PM & 3.32 & 3.13 & 50.81 \\
\hline $02-09-13$ & 4:00PM & 3.05 & 3.00 & 48.7 \\
\hline
\end{tabular}

Table, s description: The table provides us information about efficiency changes with time. At $5.00 \mathrm{pm}$ of starting day (28-08-2013) efficiency was nearly $95 \%$. With the flow of time efficiency started to decrease gradually and after five days (approximately 143 hours) it became below $50 \%$. So BPL cell, s efficiency is reverse proportional with time.

It can be noted that for better combination and avoiding circulating current between cells voltage of every cells should be equal.

\subsection{Experimental Data}

An efficiency calculation is given below for two BPL modules in parallel with a $3 \mathrm{~W}$ LED light as follow

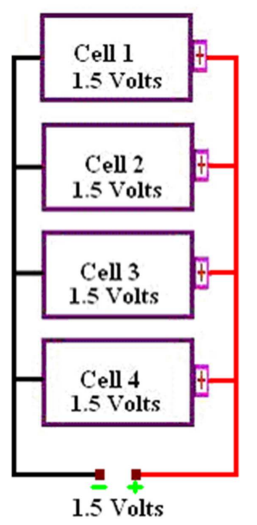

Figure 11. Parallel combination of cells. Current is four times higher than each cell current.

\subsection{Result of Experimental Data}

The initial efficiency of BPL cell $=94.97 \%$

The efficiency at dead point of BPL cell $=48.7 \%$

And the average efficiency of BPL cell $=58.86 \%$

\subsection{Series Parallel Combination of Cells}

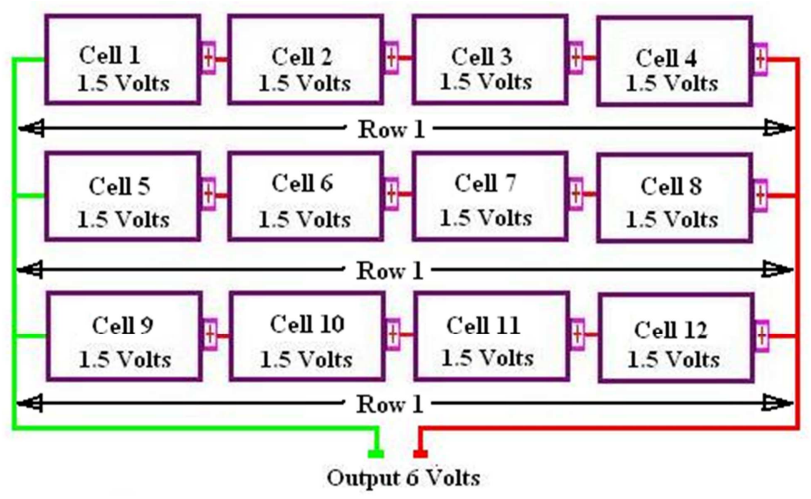

Figure 12. Series parallel combination of cells. Voltage is 4 times higher than each cell voltage and current is three times higher of each cell current. 
The most important and most useful combination of cells is the series-parallel combination. In this case some cells are connected in series to form the required voltage. Now if the current or power requirement is higher than one cell then another series combination is formed and the later series combination is connected with the pervious series combination in parallel. In this way we can increase both the system voltage and current requirement. Here we can increase the power as we need. Let us again consider the case of same dry cell battery each cell with cell voltage 1.5 volts. Now if we want to run an appliance the voltage rating of which is 6 volts and current rating as high as three cells. In such case we need 16 cells to support the required power. We need to connect four cells in series to form $1.5 \times 4=6$ volts. Let us call this cell in parallel which will increase the system current four times but will keep the system voltage the same i.e. 1.5 volts. The positive terminal of all the cells shall be connected with the positive terminal of the load and negative terminal of all the cells shall be connected with negative terminal of the load or appliances. This arrangement is shown in figure 12 below.

Here each cell voltage $=1.5$, Number of cell in a row $=4$, Total number of row $=3$

Therefore, System voltage $=$ One cell voltage $\times$ Number of cell in one row. i.e. System voltage $=1.5 \times 4$ Volts $=6$ Volts. System Current $=$ Each cell Current $\times$ Number of row in parallel. i.e. System Current $=($ Each cell current $\times 4)$ Ampere. In general, For system voltage, V System $=$ VRow 1 $=$ VRow $2=$ VRow $3=\ldots=$ V Row $n$, Where, $\mathrm{V}$ Row $=\mathrm{V}$ Cell $1+\mathrm{V}$ Cell $2+\mathrm{V}$ Cell $3+\ldots+\mathrm{V}$ Cell n, i.e. $\mathrm{V}$ Row $=$ $\sum_{\mathrm{n}}^{\mathrm{x}=1} \mathrm{~V}_{\text {Cell } \mathrm{x}}$. For system Current, I System $=$ I Row $1+$ I Row $2+$ I Row $3+\ldots+$ I Row n, i.e. I System $=\sum_{n}^{x=1} I_{\text {Row } x}$, Where I Row $=$ I Cell $1=$ I Cell $2=$ I Cell $3=\ldots \ldots .=$ I Cell $n$

It should be noted that the number of cells in each row must be the same. Otherwise a circulating current will flow through the rows and no current or few current will flow through the load. The circulation current may lead to damage the system.

\subsection{Combination of Cells}

The power we get from the cell of BPL is direct current (dc). The electrical appliances available in our country are of 6 volts, 9 volts, 12 volts etc. Since the practical appliances available in the market are of higher voltages than that of per cell voltage of BPL, so for the practical application we need to increase the system voltage by adding the multiple BPL cell in series. For example, we can get six voltage by connected the six BPL cell in series. Such an arrangement is shown in figure 13. Here six cells are used and connected in series. This will give an output voltage of 6 volts [theoretically $1.1 \times 6=6.6$ volts]. But this will keep the current same i.e. output current remain the same as per cell current.

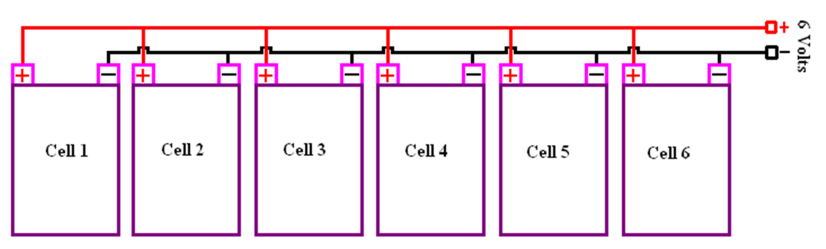

Figure 13. Six cells are connected in series for an output of six volts.

Similarly, if we want to increase both the voltage and current hence the power we need to go for series-parallel combination of the BPL cells. This will increase both output voltage and current and hence the output power. Since the power in D.C. system is the product of voltage and current. Power, $\mathrm{P}=\mathrm{V} \times \mathrm{I}$ Watts. Where, $\mathrm{P}=$ Power in Watt, $\mathrm{V}=$ Voltage in Volts, $\mathrm{I}=$ Current in Ampere. Figure 14 shows such a system which will provide a output voltage 12 volts and will provide current equal to two BPL cells.

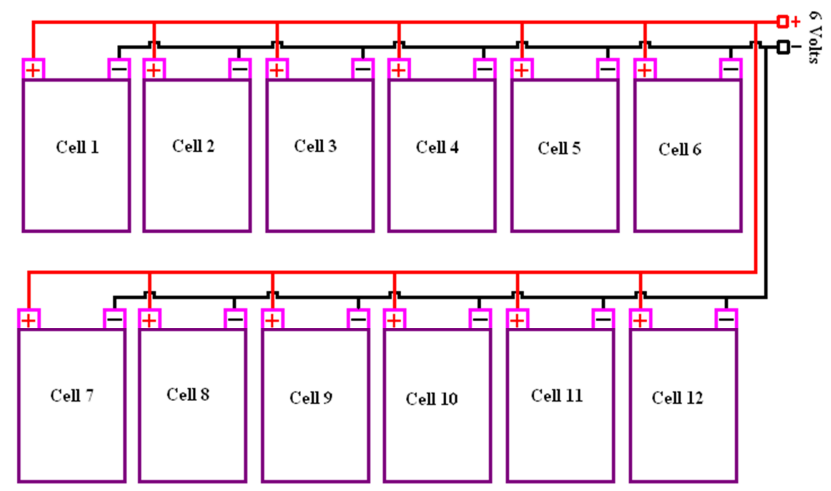

Figure 14. Twelve cells are connected in series-parallel combination to get an output of 6 volts with increases power.

If we want to get more power we will need to use more cells in series parallel combination of cells.

\subsection{Process of Electricity Production}

When the connections of electrodes are ready we are at the final stage of producing electricity from BPL At this stage the final task is to pouring the juice of BPL to the container or pot where the electrodes are placed. A chemical reaction occur, which in turn, creates positive and negative potentiality around the plates. Now if we connect the Zinc and Copper plate through a proper load the current will flow from the cell to the external circuit. Oxidation will take place at anode (Zinc) and reduction at the cathode (Copper). This will create a flow of electrons from zinc to copper and will produce current in the circuit. The net cell reaction will be as below:

$$
\mathrm{Zn}+\mathrm{Cu}^{2+} \longrightarrow \mathrm{Zn}^{2+}+\mathrm{Cu}
$$

Thus metal at anode loses electrons and dissolved and metal at cathode gains electrons and grows. An experimental setup of the process is illustrated in figure- 15 below. 


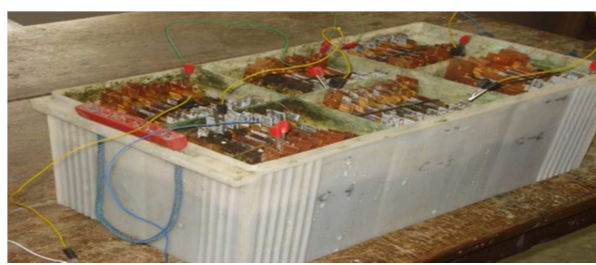

Figure 15. Experimental Setup of Cells of BPL

The graphical representations of-

1. Current (A) Vs Potential (Volt)

2. Potential (Volt) Vs Concentration of $\mathrm{Cu}^{2+}(\mathrm{ppm})$

3. Concentration of $\mathrm{Cu}^{2+}$ (ppm) Vs Time (hour) are given below-

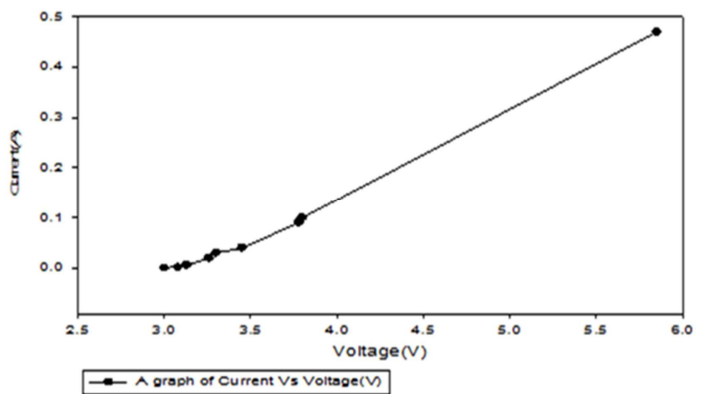

Graph 1. Illustrates relation between current \& potential. At the very beginning when voltage was around $3 v$ then current was negligible. Amount of current increased with increasing voltage.

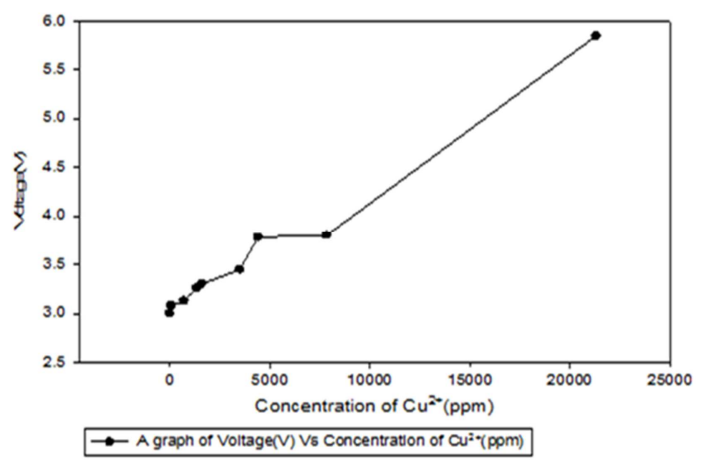

Graph 2. Explicate the characteristics how voltage changes with change of concentration density. When concentration density was nearly zero then the voltage was below $3 v$. with some fluctuations voltage increased with the increase of concentration density. Between 4800-9800ppm voltage remained leveled off. Next $15000 \mathrm{ppm}$ voltage rose minimally nearly $6 \mathrm{v}$.

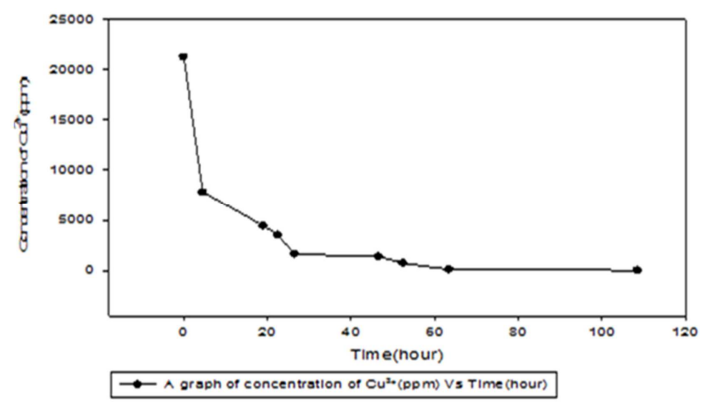

Graph 3. Shows concentration density changes with time. At the very beginning concentration rate was more than 20000ppm. Within five hours it dropped dramatically to nearly 1000ppm.Next fifteen hours it declined proportionally. After sixty-five hours it became stabilized.

\subsection{Problems of the BPL Electricity Production}

As other cells BPL cell has also some common problem in producing electricity. It has seen that there are two problems in BPL electricity generation system Local Action and Polarization.

\subsection{Public Desire about BPL Electricity}

Usability of any technology not only technical based; but public acceptability is also very much important. Therefore, to know about the public desire about BPL electricity we undergo a small survey. The main objective of this survey was to know the willingness to use this technology.

1 the duration of use of electricity at night for lighting.

2 the expected cost for the system.

3 No need to use any extra fuel.

4 From only one liter of filtered fresh BPL juice we can generate electricity month after month.

\section{Conclusion}

The generation of electricity from BPL is quite simple and easy. This is the invention of our own. The poor villagers or the people in remote areas of the country can easily make it, can easily use it for their power need. It does not need any expensive material or in-depth knowledge about electricity to produce. Moreover since the generated electricity is of low voltage and does not use any harmful substance so it is also very much safe to produce and use. We can collect or easily cultivate the BPL in a corner of our unused land. Easily collect the electrodes from the local market and can made it easily. Last of all, From only one liter of filtered fresh BPL juice we can generate electricity month after month. The reserve of organic fossil fuel will be about to finished with in the $2^{\text {nd }}$ half of this century. Our invention will play a vital role to enlighten the rural area of the world.

\section{References}

[1] D.A. Alabi, M.Z. Onibudo1 and N.A. Amusa, "Chemicals and Nutritional Composition of Four Botanicals with Fungitoxic Properties", Published in World Journal of Agricultural Sciences, 2005, Vol. 1(1): P 84-88.

[2] RA. McKenzie and PJ. Dunster, "Hearts and flowers: Bryophyllum poisoning of cattle". Australian veterinary journal, 1986, Vol. 63 (7): P 222-227.

[3] CA. Lans, "Ethnomedicines used in Trinidad and Tobago for urinary problems and diabetes mellitus". J Ethnobiol Ethnomed, 2006, Vol. 2: P 45.

[4] A. Sharma, C. Shanker, L.K. Tyagi, M. Singh and C.V. Rao, "Herbal medicine for market potential in India: An overview". Acad. J. Plant Sci., 2008, Vol. 1: P 26-36.

[5] B. Joseph, R.M. Priya, P.A.M. Helen and S. Sujatha, "Bioactive compounds in essential oil and its effects of antimicrobial, cytotoxic activity from the Psidium guajava (L.) Leaf'. J. Adv. Biotechnol., 2010, Vol. 9: P 10-14. 
[6] B. Joseph, S. Sridhar, Sankarganesh, Justinraj and T. Biby Edwin, "Rare Medicinal Plant- Kalanchoe pinnata." Research Journal of Microbiology, 2011, Vol. 6: P 322-327.

[7] L. Taylor, Herbal secret of rainforest, 2nd edition, sagca press Inc, 2003.

[8] A. Sofowora, Medicinal plants and traditional medicine in Africa, 2nd edition, John Wiley spectrum book limited, Ibadan, 1993, P 214-220.

[9] Y. Tanko, A. Mohammed, M.I.A. Saleh, K.A. Mohammed, E. Etta, I.G. Bako, A. Muhammad, and M. Yerima, "Antinociceptive and Anti-Inflammatory Activities of Ethanol Extract of Bryophyllum Pinnatum Laboratory Animals", IOSR Journal of Dental and Medical Sciences (JDMS), 2012, Vol. 3: P 46-49.
[10] Muhammad Afzal., Imran Kazmi., Ruqaiyah Khan., Rajbala Singh., Mohit Chauhan., Tanvi Bisht, and Firoz Anwar, "Bryophyllum pinnatum: A review", International Journal of Research and Biological Sciences, 2012, Vol. 2(4): P 143-149.

[11] J. Sultana, K.A. Khan, and M.U. Ahmed. "Electricity Generation From Pathor Kuchi Leaf(PKL) (Bryophillum Pinnatum).” J. Asiat Soc. Bangladesh Sci., 2011, Vol. 37(4): P 167-179.

[12] A. K. Covington, R. G. Bates, and R. A. Durst,)."Definitions of $\mathrm{pH}$ scales, standard reference values, measurement of $\mathrm{pH}$, and related terminology". Pure Appl. Chem, 1985, Vol. 57 (3): P 531-542. 